\title{
АКТУАЛЬНЫЕ ПРОБЛЕМЫ ЯЗЫКОВОЙ ПОЛИТИКИ РОССИИ НА СОВРЕМЕННОМ ЭТАПЕ
}

\section{MODERN TENDENCIES OF LANGUAGE POLICY OF RUSSIA AT THE PRESENT STAGE}

\section{N. Yudina \\ M. Melnichuk}

Summary: The article examines the language policy of the Russian Federation as a whole and outlines the main tasks of the language policy aimed at strengthening national interests and strengthening the position of the Russian language abroad. The purpose of the article is to determine the importance of the Russian language for international academic mobility and, as a consequence, the increase of the level of export of Russian education. The research methodology is based on general scientific methods of cognition: induction, deduction and comparative analysis, which are supported by a graphical method of data visualization.

Keywords: language policy; knowledge economy; Russian language; higher education.

\author{
Юдина Наталья Владимировна \\ Д.филол.н., профессор, Финансовый университет при \\ Правительстве РФ \\ NVYudina@fa.ru \\ Мельничук Марина Владимировна \\ Д.э.н., профессор, Финансовый университет при \\ Правительстве РФ \\ MVMelnichuk@fa.ru
}

Аннотация: В статье рассматривается языковая политика Российской Федерации в целом и обозначены основные задачи языковой политики, направленные на укрепление национальных интересов и усиление позиций русского языка за рубежом. Целью статьи является определение значимости русского языка для международной академической мобильности и, как следствие, повышения уровня экспорта российского образования. Методология проведенного исследования базируется на общенаучных методах познания: индукции, дедукции и методе сравнительного анализа, которые подкреплены графическим методом визуализации данных.

Ключевые слова: языковая политика; экономика знаний; русский язык; высшее образование.
$\mathrm{H}$ а основополагающую роль языка в определении национальной идентичности указывали еще мыслители Древней Греции. Неудивительно, что каждое государство стремится выстроить свою языковую политику таким образом, чтобы фундаментальная роль языка в деле существования нации сказывалась наиболее благоприятным образом на существовании государства, и язык в полной мере выполнял свою консолидирующую функцию, являясь детерминантой сплоченности граждан [1-6]. Долгие годы такая консолидирующая роль отводилась русскому языку, но распад СССР с последующим образованием целого спектра независимых территориальных объединений, проводящих свою собственную национальную языковую политику, привели к изменению статуса русского языка в этих вновь образованных государствах и, как следствие, во всем мире. Безусловно, такие изменения были прогнозируемы и в какой-то степени обоснованы. Но в связи со сложившейся ситуацией как никогда актуальной становится реализация следующих направлений государственной языковой политики в призме геополитических интересов России: «расширение зоны влияния, поддержание русскоязычной диаспоры за рубежом, восприятие русского языка как полноправного и полноценного участника широкой коммуникации в рамках как своего многонационального государства, так и мирового сообщества» [7].

Приняв участие в заседании Совета по русскому языку, созданному в 2014 г. и подчеркнув тем самым его значимость, Президент России заявил о том, что совершенствование государственной политики в области поддержки русского языка является приоритетной задачей всех органов власти и что наша страна несет ответственность за сбережение русского языка в условиях глобализации, поэтому крайне важно предотвратить все попытки «вытеснить его на периферию» [8].

Статистические данные говорят о том, что в настоящее время 146 млн. граждан Российской Федерации используют русский язык как средство коммуникации и еще 127 млн. человек делают это за рубежом (рис.1). Для сравнения представим данные о числе владеющих другими языками, в том числе и русским (рис.2).

Еще в 2018 г. эксперты Министерства образования и науки пришли к выводу, что количество иностранцев, целенаправленно занимающихся русским языком, снизилось на 50\%. Прогноз, который они представили, вызывает тревогу и обеспокоенность: так, к 2025 г. число владеющих русским языком составит 2,7\% от доли общемировой численности населения, а к 2050 г. - упадет до 1,4\%, что в 2,5 и 5 раз меньше показателей 1980 г. (рис. 3). Конечно, нельзя не принимать в расчет геополитические реалии 1990-х годов, когда произошло катастрофическое снижение интереса к русскому языку и в странах бывшего соцлагеря и в странах, являющимися бывшими 


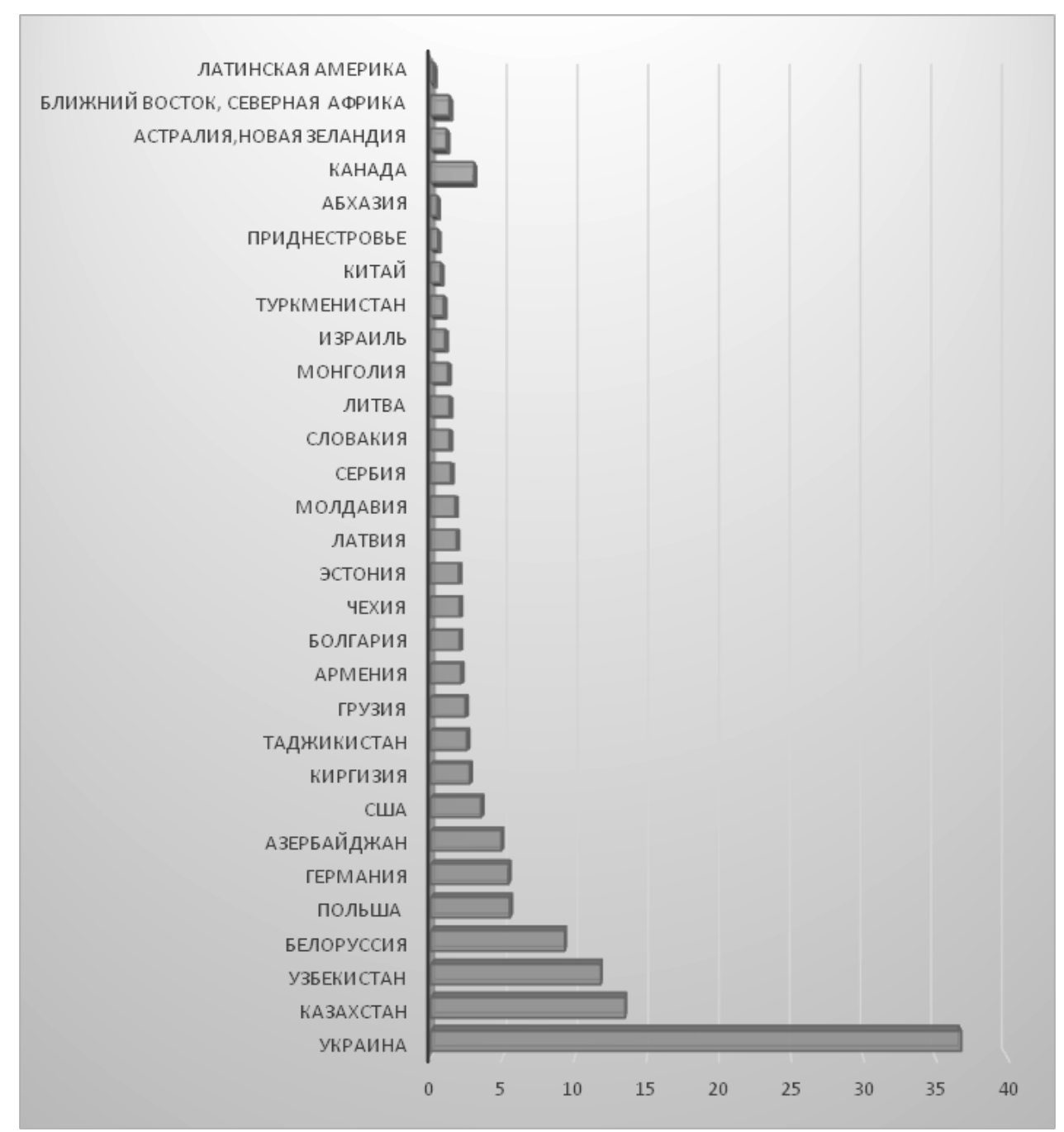

Рис. 1. Количество людей, владеющих русским языком за рубежом (млн. чел.) в межстрановом разрезе. Источник: https://rs.gov.ru/\%C2\%A0/activities/9 [9]

республиками СССР. Но, к сожалению, говорить о том, что ситуация выравнивается, не приходится.

На наш взгляд, частичное решение данной проблемы должно быть возложено на организации, которые курируют обучение иностранцев за рубежом: именно они должны максимально способствовать созданию таких условий на территории стран, нуждающихся в поддержке русского языка, чтобы у граждан появлялась возможность качественного его изучения с целью в дальнейшем получения высшего образования либо в российских вузах на русском языке, либо на английском языке в рамках международных программ, реализуемых в российских вузах. Таким образом, перед данными институтами должна быть поставлена задача разработки своеобразной матрицы поддержки и расширения использования русского языка за рубежом, которая определила бы возможные траектории решения проблемы (рис. 4,5).

Экономика знаний, в которой человеческому капи- талу отводится роль ключевого игрока в осуществлении качественных преобразований, вызванных четвертой индустриальной революцией, вызвала небывалый подъем рынка образовательных услуг в мире, прежде всего на уровне высшего образования. Как следствие, в борьбу за потенциального студента включились не только страны с развитой экономикой, но и государства, находящиеся на переходном этапе своего экономического развития. И в данном случае экспорт высшего образования становится еще одним важным вектором реализации государственной языковой политики любой страны, призванным санкционировать активное движение своих институтов в этом направлении и целенаправленное вовлечение в данный процесс всех заинтересованных организаций, а также разработать стратегию по достижению максимальных объемов экспорта образовательных услуг, поскольку в конечном итоге речь должна идти об увеличении темпов экономического роста за счет прироста знаний и увеличения интеллектуального капитала (рис. 6). 


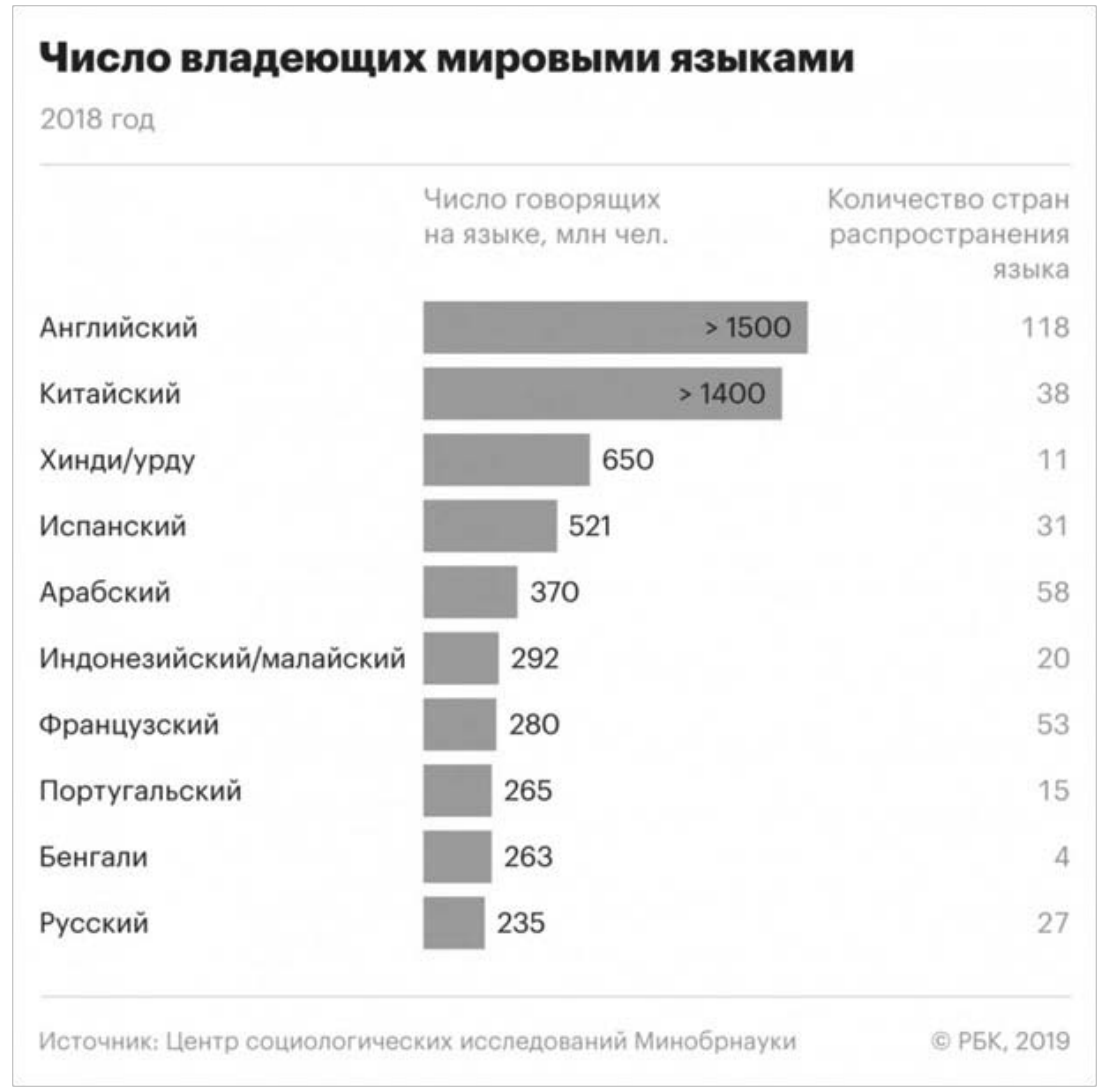

Рис. 2. Количество людей, владеющих мировыми языками, в том числе и русским языком (млн. чел.). Источник: https://www.rbc.ru/society/28/11/2019/5ddd18099a79473d0d9b0ab1 [10]

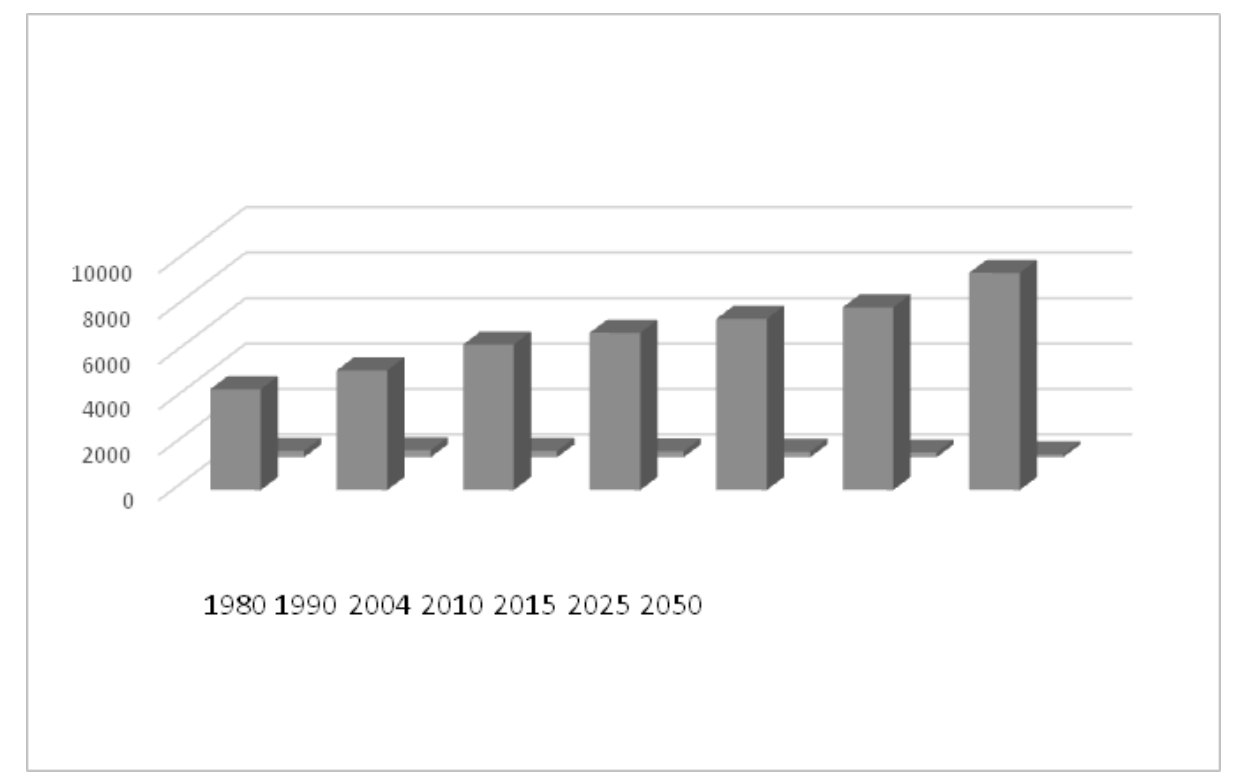

Рис. 3. Изменение удельного веса владеющих русским языком с 1980 по 2050 г.

Голубым цветом обозначена общемировая численность населения, оранжевым - количество людей, владеющих русским языком (прогноз экспертов). Источник: www.unkniga.ru

Интересно отметить, что до определенного времени Всемирный банк осуществлял программу «Знания для развития», ключевым моментом которой была разработанная этой организаций методика подсчета индек- са экономики знаний и индекса знаний (рис. 7). Оценка вышеуказанных индексов происходила на основании 148 показателей, объединенных в четыре основные группы: экономические стимулы и институциональ- 


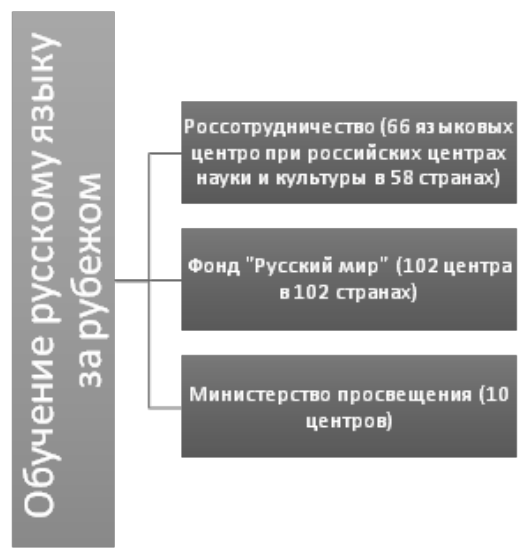

Рис. 4. Организации, в ведении которых находится обучение русскому языку за рубежом. Источник: https://www.rbc.ru/society/28/11/2019/5ddd18099a79473d0d9b0ab1 [10].

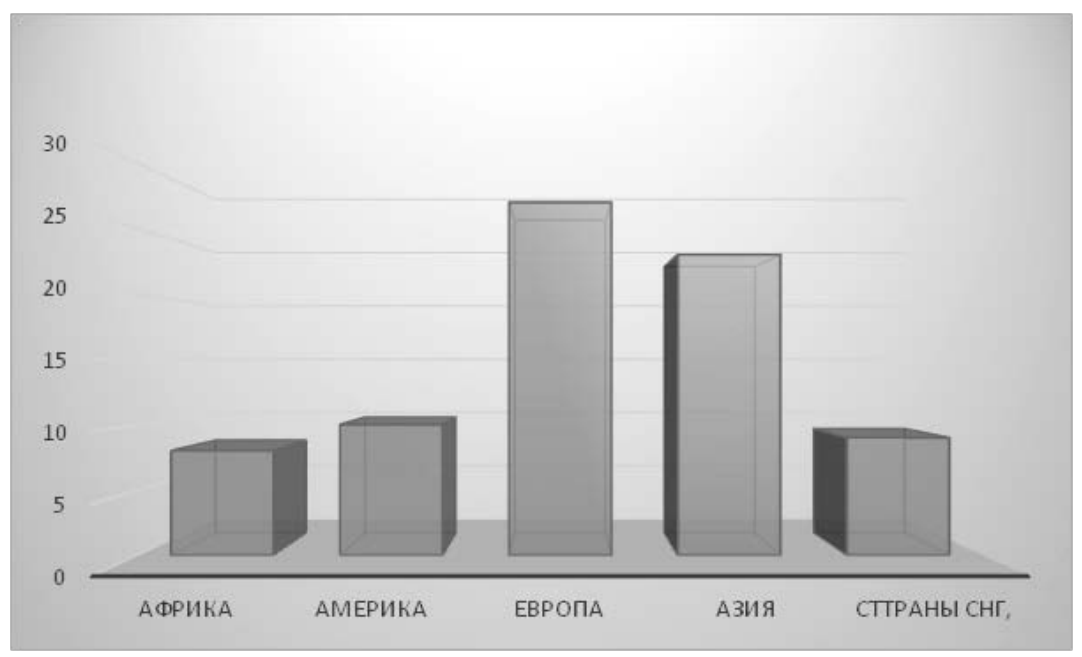

Рис. 5. Количество зарубежных представительств Россотрудничества. Источник: https://rs.gov.ru/ru/contacts

ная среда, система образования и подготовки кадров, инновационный потенциал и технологическое развитие, индекс информационных технологий и телекоммуникации [12].

Анализ данных индексов позволил выявить корреляцию между странами с развитой экономикой и высоким показателем индекса знаний. И, наоборот, наименее развитые страны имели низкий показатель индекса знаний. Таким образом, интеллектуальные ресурсы страны начинают становиться ключевым драйвером экономического роста государства и становятся катализатором для перехода университета к инновационной модели 4.0.

Для того чтобы высшее учебное заведение могло эффективно участвовать в экспорте услуг высшего образования, оно должно иметь ряд преимуществ:

- активно вести междисциплинарные исследования;

- реализовывать практико-ориентированные проекты по запросам работодателей;
- иметь собственный бизнес-инкубатор с коммерческой составляющей;

- присутствовать на международном рынке с возможностью обучения, преподавания и проведения исследований в разных странах;

- создавать условия для привлечения талантливых студентов из своей страны и из-за рубежа;

- вести деятельность по привлечению лучших преподавателей-предметников из своей страны и изза рубежа.

Российские вузы в течение последних десяти лет постарались максимально использовать вышеуказанные преимущества и комплексный подход в решении поставленной задачи, что дало возможность нашей стране войти в число лидеров по количеству иностранных студентов наряду с Германией, Францией, Великобританией и США - традиционными флагманами международной студенческой мобильности. Рис. 8 наглядно демонстрирует более чем двукратное увеличение с 2007 по 2018 гг. количества студентов, приехавших получать 


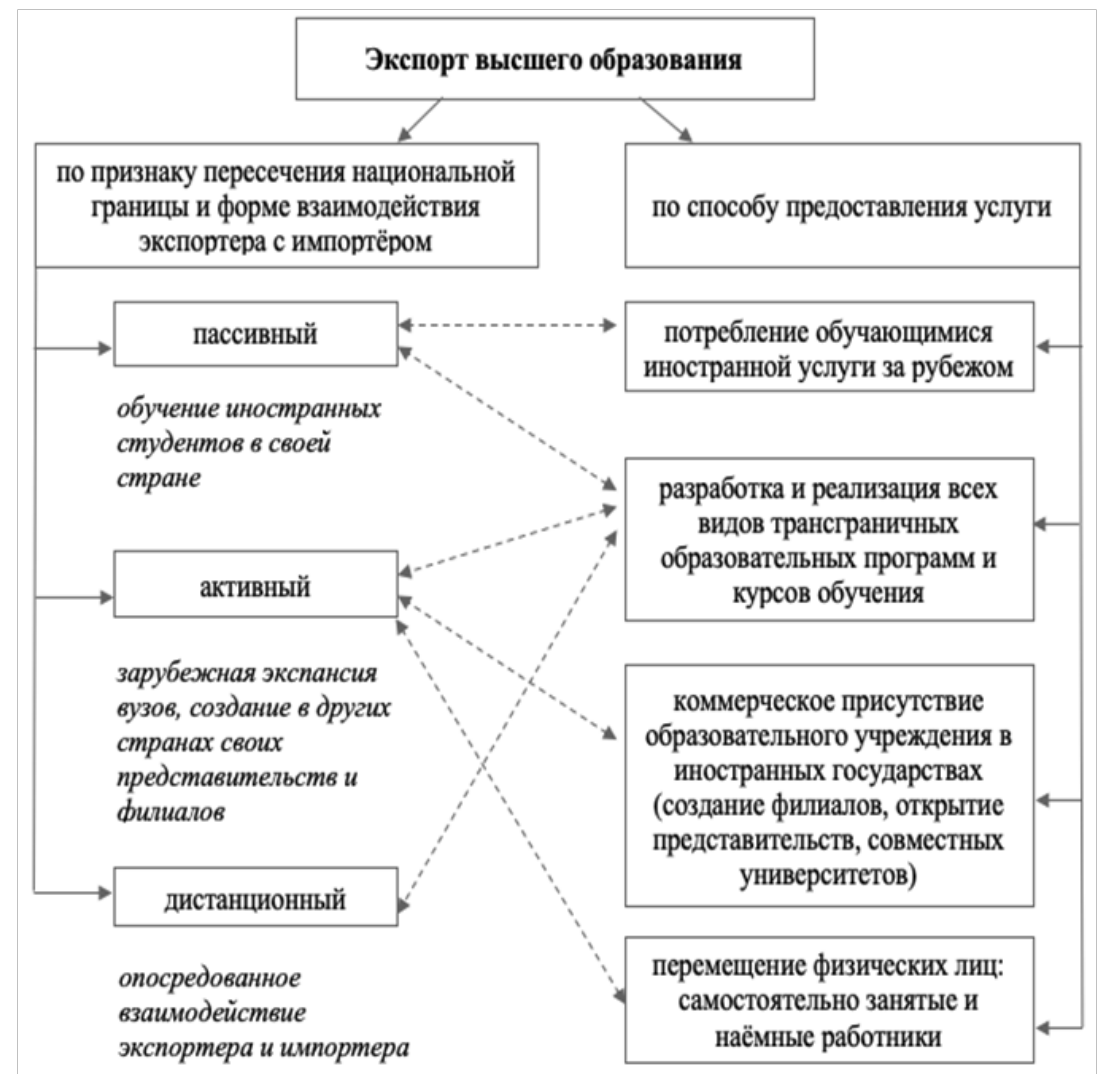

Рис. 6. Виды экспорта высшего образования.

Источники: Е. К. Защитина, П.В. Павлов. Экспорт высшего образования: прикладное исследование [11].

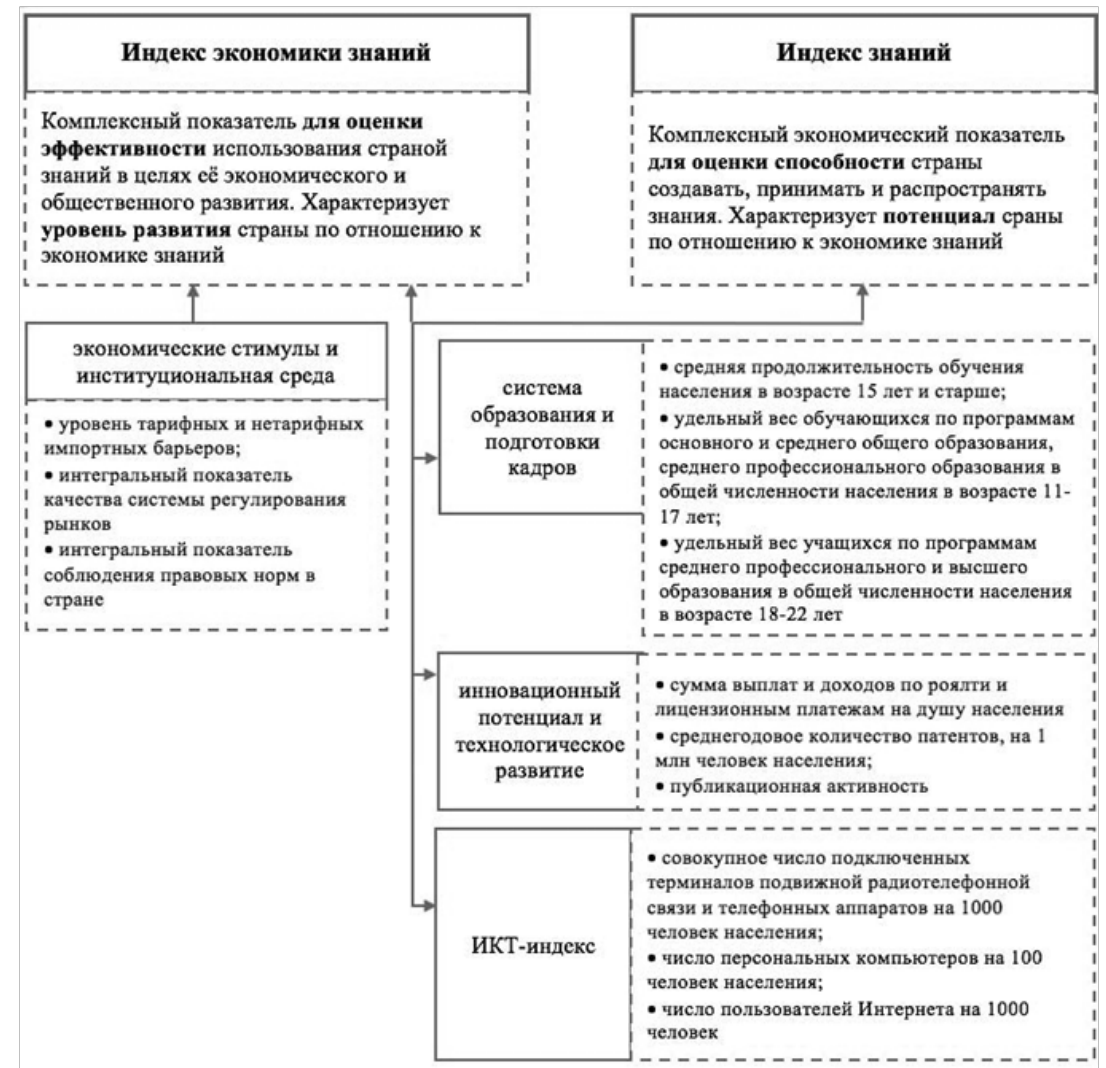

Рис. 7. Методология оценки индекса экономики знаний и индекса знаний. Источник: Е. К. Защитина, П.В. Павлов. Экспорт высшего образования: прикладное исследование. - 2019 [11]. 


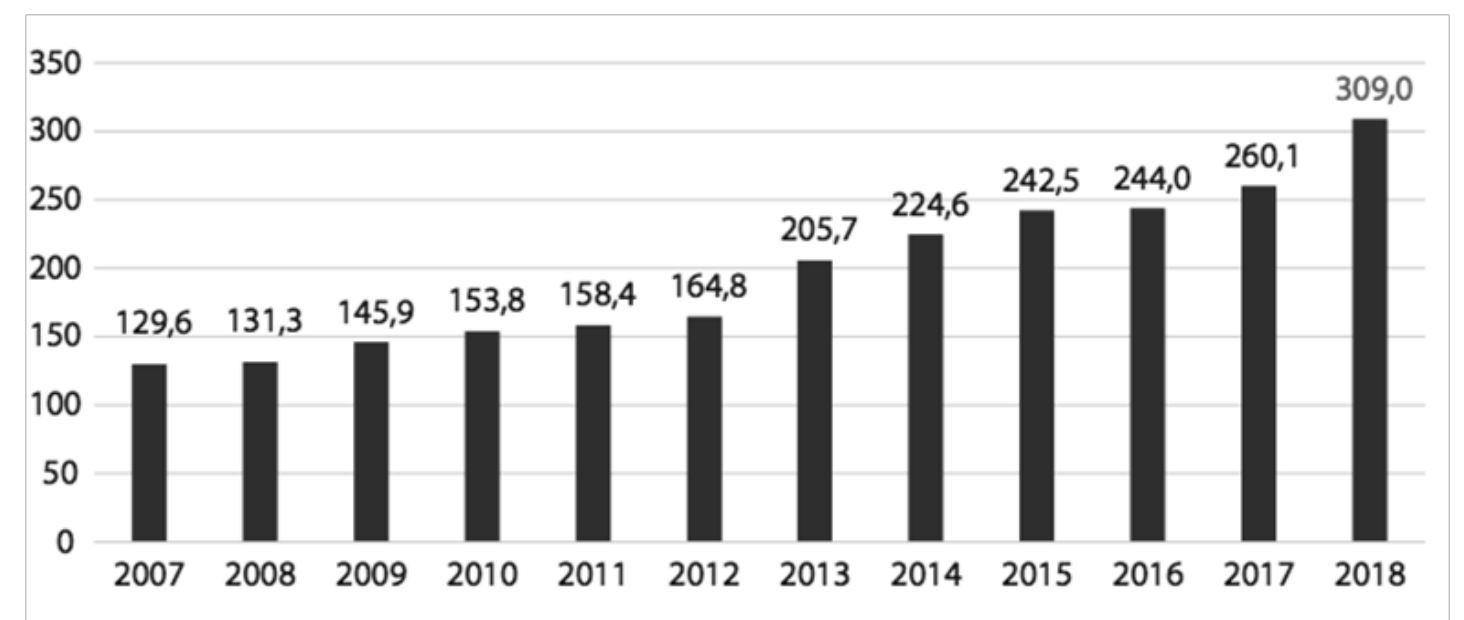

Рис. 8. Динамика количества иностранных студентов, обучающихся по программам бакалавриата, специалитета, магистратуры в российских вузах, тыс.чел. Источник: Обучение иностранных граждан в российских учреждениях высшего образования/Министерство науки и высшего образования Российской Федерации. М.: ФГАНУ «Социоцентр», 2019 [13].

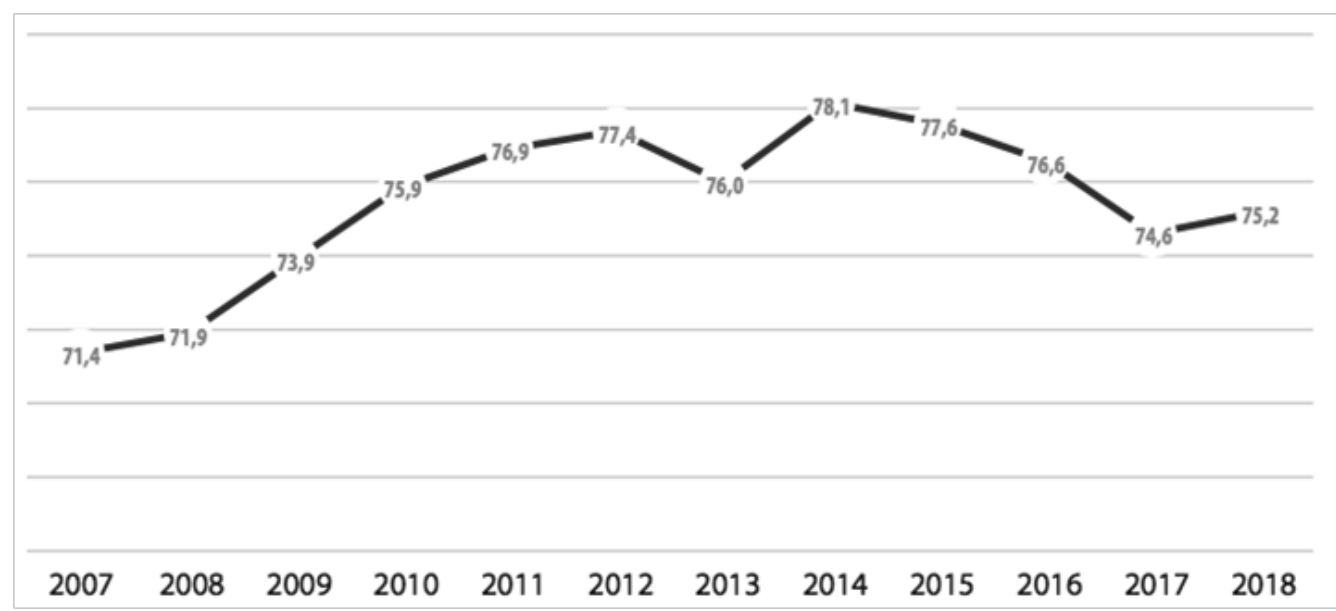

Рис. 9 Динамика доли студентов из стран СНГ, Балтии и Грузии среди всех иностранных студентов, обучающихся в российских вузах, \% . Источник: Обучение иностранных граждан в российских учреждениях высшего образования/ Министерство науки и высшего образования Российской Федерации. - М.: ФГАНУ «Социоцентр», 2019 [13].

\begin{tabular}{lcc}
\hline Страна & $\begin{array}{c}\text { Количество } \\
\text { студентов }\end{array}$ & $\begin{array}{c}\text { Доля студентов среди всех студентов } \\
\text { из стран СНГ, Балтии, Грузии }\end{array}$ \\
\hline Республика Казахстан & 73660 & 31,7 \\
Республика Узбекистан & 28650 & 12,3 \\
Туркменистан & 28269 & 12,2 \\
Республика Таджикистан & 27693 & 11,9 \\
Украина & 18759 & 8,1 \\
Киргизская Республика & 15663 & 6,7 \\
Республика Беларусь & 13216 & 5,7 \\
\hline
\end{tabular}

Рис. 10. Студенты из стран СНГ, Балтии и Грузии (по странам), чел., \%.

Источник: Обучение иностранных граждан в российских учреждениях высшего образования/Министерство науки и высшего образования Российской Федерации. - М.: ФГАНУ «Социоцентр», 2019 [13]. 
высшее образование в России из-за рубежа.

Наибольшее количество иностранных студентов, обучающихся в российских вузах, - это слушатели, приехавшие в Россию из стран СНГ - Казахстана, Туркменистана, Узбекистана и Таджикистана (рис. 9 и 10 ).

Таким образом, на основе исследований, представленных в данной статье, можно сделать следующие выводы. Институциональная политика любого государства направлена на стимулирование экономического роста, структурным базисом которого являются повышение производительности труда и конкурентоспособности, активное внедрение инноваций, повышение качества предоставляемых образовательных услуг, а надстройкой - переход к экономике знаний и цифровой экономике. Все это приводит к тому, что ключевое место в дискурсе институциональной политики начинает занимать языковая политика государства, неразрывно связанная с высшим образованием.

Статья подготовлена по результатам исследований, выполненных за счет бюджетных средств по государственному заданию Финуниверситету.

\section{ЛИТЕРАТУРА}

1. Мартынова М.Ю. Языковые процессы на Балканах как элемент национального вопроса // Этнографическое обозрение. - 2016. - № 3. - С. 16-30.

2. Бахтикиреева У.М. Русский - полинациональный язык? // Вестник Российского университета дружбы народов. Сер. Лингвистика. - 2014. - № 2. - С. 16-30.

3. Сомин А.А. Языковая рефлексия в современной Беларуси сквозь призму комментариев в интернет-СМИ // Вестник РГГУ. Сер. История. Филология. Культурология. Востоковедение. - 2015. - № 1 (1). - С. $62-86$.

4. Павленко А. Языковые ландшафты и другие социолингвистические методы исследования русского языка за рубежом // Вестник Российского университета дружбы народов. Сер. Лингвистика. - 2017. - Т. 21. - № 3. - С. 493-514.

5. Фарукшин М.Х. Статус официальных языков этнических общностей в полиэтнических государствах // Социологические исследования. — 2017. № 7. - C.77-87.

6. Суюнбаева А.Ж., Шелестюк Е.В. Проблемы переходной диглоссии и функционирование билингвизма в профессиональной коммуникации (на примере языковой ситуации в республике Казахстан). - Вестник Челябинского государственного университета. - 2019. - № 10 (432). -С. 149-164.

7. Петрулевич И.А., Месропян Л.М. Современная языковая политика Российской Федерации: основные векторы и тенденции развития // Гуманитарий Юга России. - 2015. - С. 66-76.

8. Заседание Совета по русскому языку [Электронный ресурс]. Режим доступа: http://kremlin.ru/events/president/news/61986

9. Укрепление позиций русского языка [Электронный ресурс]. Режим доступа: https://rs.gov.ru/\%(2\%A0/activities/9

10. Число изучающих русский язык в мире упало в два раза со времен распада СССР [Электронный ресурс]. Режим доступа: https://www.rbc.ru/society/28/1 1/2019/5ddd18099a79473d0d9b0ab1

11. Защитина Е.К., Павлов П.В. Экспорт высшего образования: прикладное исследование: монография. - Ростов-на-Дону; Таганрог: Издательство Южного федерального университета, 2019. - 184 c.

12. Żak K. The knowledge economy - the diagnosis of its condition in selected countries / Studia Ekonomiczne. Zeszyty Naukowe Uniwersytetu Ekonomicznego w Katowicach № 271. - 2016 - pp. 176-187 [Электронный ресурc].URL: http://yadda.icm.edu.pl/yadda/element/bwmeta1.element.cejsh-830242e1-2713-460ea2db 053fbb334dde/c. pdf

13. Гурко Д.Д., Тростянская И.Б., Сема Е.Ю., Барсуков А.А., Полихина Н.А. Обучение иностранных граждан в российских учреждениях высшего образования/ Министерство науки и высшего образования Российской Федерации. — М.: ФГАНУ «Социоцентр», 2019. — 308 стр.

( Юдина Наталья Владимировна (NVYudina@fa.ru), Мельничук Марина Владимировна (MVMelnichuk@fa.ru).

Журнал «Современная наука: актуальные проблемы теории и практики» 